\title{
The Electrophysiological MEMS Device with Micro Channel Array for Cellular Network Analysis
}

\author{
Wataru Tonomura Non-member (Ritsumeikan University, rm007017@se.ritsumei.ac.jp) \\ Toshiaki Kurashima Non-member (University of Tokyo) \\ Yuzo Takayama Non-member (University of Tokyo) \\ Hiroyuki Moriguchi Non-member (University of Tokyo) \\ Yasuhiko Jimbo Member (University of Tokyo) \\ Satoshi Konishi Member (Ritsumeikan University)
}

Keywords : micro channel array, cellular network analysis, pt-black electrode

This paper describes a new type of MCA (Micro Channel Array) for simultaneous multipoint measurement of cellular network. Presented MCA is designed for advanced neural network analysis which has been studied by co-authors using 64ch MEA (Micro Electrode Arrays) system. First of all, sucking and clamping of cells through channels of developed MCA is expected to improve electrophysiological signal detections. Electrophysiological sensing electrodes integrated around individual channels of MCA are electrically isolated for simultaneous multipoint measurement.

Perforated microelectrode arrays for parallel recording of neural activity are reported by U. Egert's group. Via holes in their device are for efficient superfusion and stabilization $\mathrm{pH}$ in the tissue, while channels of our MCA are for sucking. This paper proposes $64 \mathrm{ch}$ isolated MCA integrated with sucking holes and electrodes for simultaneous multipoint measurement of cellular network. Figure 1 illustrates schematic drawing of $64 \mathrm{ch}$ isolated MCA. Advancements from previous MCA are as follows: 1) Platinum black as electrode for larger surface area; 2) Parylene as insulator for high biocompatibility.

The 64ch isolated MCA is developed based on the MEA system by Jimbo's group. They have obtained remarkable research achievements through neuronal recording and stimulation system by the MEA system. The $64 \mathrm{ch}$ isolated MCA is designed to improve sensitivity by sucking and fixing cell on electrode. Sucking by MCA will solve a difficulty in signal detection of cell which easily separates from electrode.

Figure 2 shows photographs of fabricated 64ch isolated MCA. Whole view of $64 \mathrm{ch}$ isolated MCA is shown in Fig. 2 (a). 64 isolated Pt-black electrodes with respective sucking holes are shown in Fig. 2 (b). The diameter of suction hole and insulator

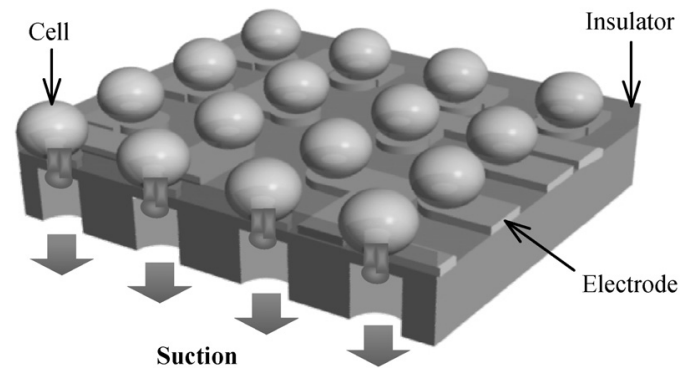

Fig. 1. Schematic drawing of the $64 \mathrm{ch}$ isolated MCA hole are $\Phi 5 \mu \mathrm{m}$ and $\Phi 10 \mu \mathrm{m}$, respectively (Fig. 2 (c)). It was possible to obtain lower electrode impedance (around $80 \mathrm{k} \Omega$ at 1 $\mathrm{kHz}$ ) by fabricated Ti/Pt-black electrode.

Figure 3 shows experimental results from major four channels could measure spontaneous action potential of rat's cortical slice simultaneously. The amplifier settings were 2,000 times gain, 10 $\mathrm{Hz}$ and $5 \mathrm{kHz}$ band path filtering. Measured extracellular spike level was around $150 \mu \mathrm{V}$ and response time was for a few milliseconds. Our 64ch isolated MCA could measure spontaneous action potential of the slice at multiple points simultaneously.

As the next step for cellular network analysis, we could culture the hippocampal neurons on developed MCA for 7 DIV (Days in vitro). Given the results described here, further studies of single cells and cellular networks are now underway by using developed MCA with Pt-black electrodes for cellular network analysis.

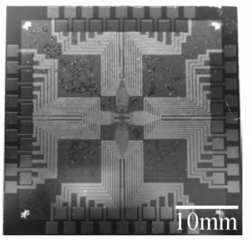

(a) Whole view.

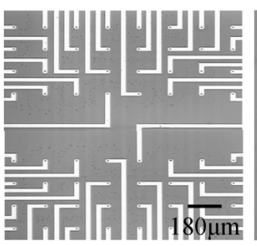

(b) 64 isolated electrodes.

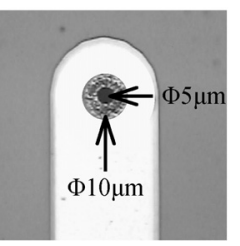

(c) Close-up of a channel.
Fig. 2. Fabrication results of the $64 \mathrm{ch}$ isolated MCA

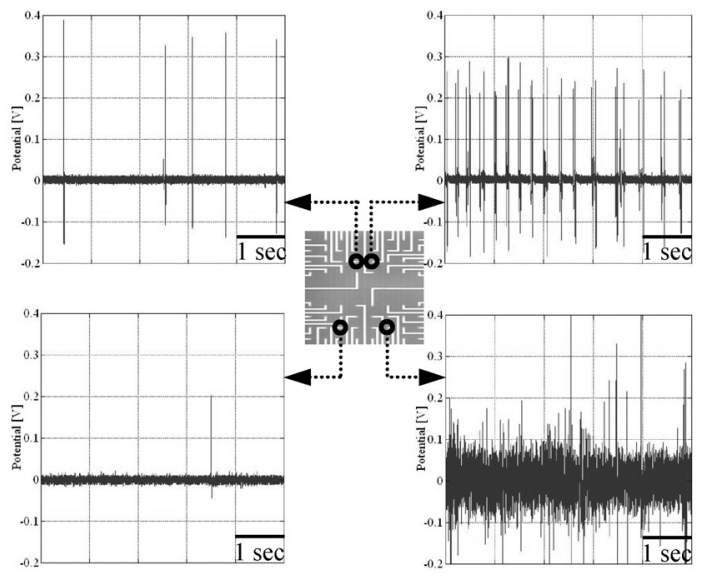

Fig. 3. Simultaneous multipoint measurements of slice's spontaneous action potential in suction 


\section{マイクロチャンネルアレイ構造を有した 細胞間ネットワーク解析用デバイス}

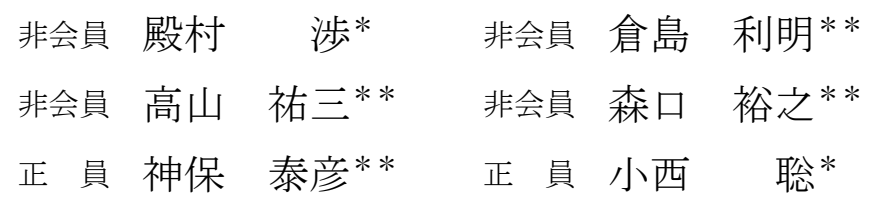

The Electrophysiological MEMS Device with Micro Channel Array for Cellular Network Analysis Wataru Tonomura*, Non-member, Toshiaki Kurashima**, Non-member, Yuzo Takayama**, Non-member, Hiroyuki Moriguchi**, Non-member, Yasuhiko Jimbo**, Member, Satoshi Konishi*, Member

This paper describes a new type of MCA (Micro Channel Array) for simultaneous multipoint measurement of cellular network. Presented MCA employing the measurement principles of the patch-clamp technique is designed for advanced neural network analysis which has been studied by co-authors using 64ch MEA (Micro Electrode Arrays) system. First of all, sucking and clamping of cells through channels of developed MCA is expected to improve electrophysiological signal detections. Electrophysiological sensing electrodes integrated around individual channels of MCA by using MEMS (Micro Electro Mechanical System) technologies are electrically isolated for simultaneous multipoint measurement. In this study, we tested the developed MCA using the non-cultured rat's cerebral cortical slice and the hippocampal neurons. We could measure the spontaneous action potential of the slice simultaneously at multiple points and culture the neurons on developed MCA. Herein, we describe the experimental results together with the design and fabrication of the electrophysiological MEMS device with MCA for cellular network analysis.

キーワード : マイクロチャンネルアレイ, 細胞ネットワーク解析, 白金黒電極

Keywords : micro channel array, cellular network analysis, pt-black electrode

\section{1. 緒言}

生命のメカニズムを解明する上で観察対象は数多くある が，生命機能を維持している最小固体である細胞が重要な 観察対象として非常に注目されている。代表的な研究例と して, シリコンやガラスに単一の吸引孔を形成した細胞解

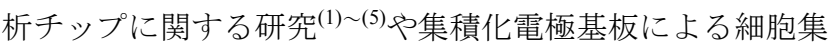
団のネットワークシグナル伝達に関する研究 ${ }^{(6)}$ (8), また脳 の視交叉上核に存在する時計遺伝子によってもたらされる 概日リズムに関する研究(9)が挙げられる。これらの研究の進 展により生命のメカニズムが徐々に解明され始めている。

細胞の電気的活動を観察する一般的な手法としてパッチ

\footnotetext{
* 立命館大学

厂525-8577 滋賀県草津市野路東 1-1-1

Ritsumeikan University,

1-1-1 Noji-higashi, Kusatsu, Shiga 525-8577

** 東京大学

T277-8583 千葉県柏市柏の葉 5-1-5

University of Tokyo,

5-1-5 Kashiwanoha, Kashiwa, Chiba 277-8583
}

クランプ法や集積化電極基板 (Micro Electrode Arrays; MEA) が挙げられる。本研究室では, パッチクランプ法における 問題点, すなわちガラス管微小電極ピペットの製作・操作 が困難, またロースループット等を克服するために, MEMS (Micro Electro Mechanical System) 技術を用いて, 細胞吸引孔 と検出電極を一体化したマイクロチャンネルアレイ (Micro Channel Array; MCA) 構造を有する細胞電気信号計測用デ バイスの研究に取り組んできた ${ }^{(10) \sim(13)}$ 。先行デバイスと比較 し MCA は, 観測対象を吸引固定して接触状態を向上するこ とで，優れた検出感度をもつ細胞外計測を可能とする。

細胞電気信号計測用デバイスには, 一括計測用 MCA と個 別計測用 MCA の 2 種類がある。一括計測用 MCA では, 電 気的に独立した 1 つの検出電極に対して 100 個の吸引孔 $(\Phi 6 \mu \mathrm{m})$ が対応しているため, 多数の微小な細胞信号の総 和を 1 信号として検出することができる。一方, 個別計測 用 MCA では, 電気的に独立した検出電極がアレイ状に 16 極あり，1つの検出電極に対して 1 個の吸引孔 $(\Phi 4 \mu \mathrm{m})$ が 対応しているため, 1 細胞の信号を個別に検出することが可 
能である。

本研究では，上記 MCA を基本構造とし，細胞間ネットワ 一ク解析用 MCA デバイスの開発に取り組んでいる。細胞間 ネットワーク解析を実現するために, 吸引固定による $\mathrm{S} / \mathrm{N}$ 比の向上およびデバイス上での長期培養に向けて個別計測 用 MCA の改良を進めてきた。個別計測用 MCA は，電気的 に独立した 1 つの検出電極に 1 個の細胞吸引孔が対応して おり, 細胞を 1 つずつ所定の位置に固定することにより,

MEA に比べて細胞選択性と $\mathrm{S} / \mathrm{N}$ 比の向上が期待できる。多 数の微小な貫通孔を検出電極部以外に有する $\mathrm{MEA}^{(8)}$ も使用 されているが，長期観測に向けた細胞組織状態を保つため の貫通孔であり，本デバイスにおいては，細胞を吸引固定 するための貫通孔である。

本稿では, 64 極を有する細胞間ネットワーク解析用 MCA デバイスの設計・製作および検出電極の評価実験，また第 1 段階として, 観測対象をラット大脳皮質スライスとした多 点同時信号計測および本デバイス上での海馬神経細胞の培 養実験等について以後, 詳述することにする。

\section{2. 細胞間ネットワーク解析用 MCA デバイス}

〈2·1〉構造と仕様 細胞間ネットワーク解析用 MCA デバイスは，単一細胞と細胞間ネットワークの同時観測に 向けて, 細胞吸引孔と検出電極を一体化した MCA 構造を有 している。図 1 に本デバイス中心部の模式図を示す。

上記観測を実現するため, 従来の個別計測用 MCA デバイ スからの主な改良点として, 下記 2 点に取り組む。

(i ) 検出電極の低インピーダンス化

(ii ) 長期培養に向けた絶縁膜の高生体適合性化

従来の個別計測用 MCA デバイスでは検出電極として $\mathrm{Au}$ を使用していたが，更なる検出電極感度の向上を目指し， 表面積を増やして電極インピーダンスをより低下させるこ とが可能な白金黒電極の導入に取り組む。絶縁膜材料は, ポジ型感光性材料である CRC-8300（住友ベークライト株式 会社）を使用していたが，培養開始約 1 週間で基板から剥 離してしまうため, 長期培養に向けて高い生体適合性かつ 基板への密着性を有するパリレン C（日本パリレン株式会 社）の導入に取り組む。パリレン C は化学蒸着（CVD）法 により形状に均一に皮膜できるため, デバイス製作の最終 工程で細胞吸引孔径を調整できる特徽も有する。

本デバイスは，多点同時かつ低ノイズの計測を実現する

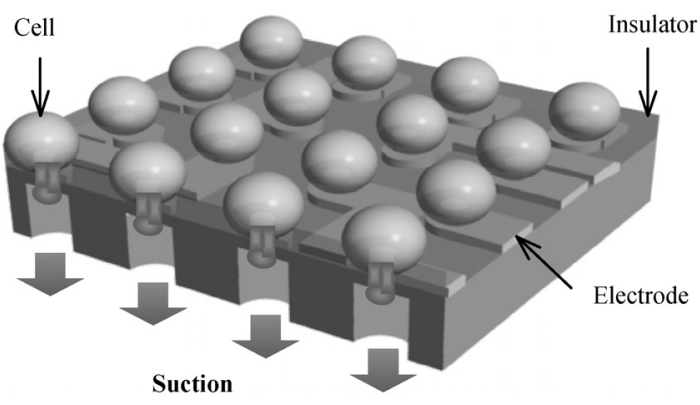

Fig. 1. Schematic drawing of $64 \mathrm{ch}$ isolated MCA.
ために使用した, 神保ら ${ }^{(6) \sim(7)} に よ り$ 開発された MEA システ ムの計測系に合わせた仕様となっている。神保らは, 開発 した MEA システムにより, 外部刺激に対する細胞集団ネッ トワークの研究において顕著な成果を得ている(6) (7)。 MEA との相違点として, 本デバイスでは検出電極上に細胞を吸 引固定するため, $\mathrm{S} / \mathrm{N}$ 比の向上および細胞選択性の面で有利 であり，効果的な細胞間ネットワークの観測が期待できる。 また, MEA では困難であった検出電極から浮遊する細胞の 観測についても，吸引固定により可能になると考えられる。 細胞間ネットワークにおける多点同時計測を目指した本 デバイスは, 細胞吸引孔と一体化した検出電極をアレイ状 に64 極, 電気的に独立した状態で有している。観測対象の 細胞サイズ（約 $\Phi 10 \mu \mathrm{m}$ ) を考慮して, 細胞吸引孔と絶縁膜 開口部の径は, 各々 $\Phi 4 \mu \mathrm{m}, \Phi 6 \mu \mathrm{m}$ とした。また, 細胞吸 引孔間距離は, 単一細胞培養における軸索の成長範囲と本 デバイスのアレイ数を考慮して, $180 \mu \mathrm{m}$ とした。

尚, 本デバイスの構造自体はチャンネル毎の個別吸引に 対応しているが, 本稿では, 細胞吸引固定の有無による信 号計測に重点を置いているため, 吸引形式は一括で行なう。 将来的には, 個別吸引用治具を用いて, チャンネル毎の個 別吸引を行なう予定である。

〈2·2〉検出原理 本デバイスは吸引固定による $\mathrm{S} / \mathrm{N}$ 比と細胞選択性に優れた細胞外計測を実現するために, 細 胞吸引孔と電気的に独立した検出電極が一体化した MCA 構造を有している。 $\mathrm{Si}$ 基板の表面に直径数 $\mu \mathrm{m}$ の細胞吸引 孔, 裏面に陰圧を加えるための直径 $100 \mu \mathrm{m}$ の吸引孔を形成 し, 個々の吸引孔を電気的に絶縁するために Si 基板表面を 酸化する。その後, 直径数 $\mu \mathrm{m}$ の細胞吸引孔と対応するよう に検出電極を形成し, 最後に各検出電極を電気的に絶縁す るために絶縁膜を成膜, パターニングしている。これによ り, 個々の細胞吸引孔において $\mathrm{S} / \mathrm{N}$ 比と細胞選択性に優れ た細胞外計測を実現することが可能である。

細胞懸濁液を本デバイス基板表面上に撒布後, 吸引用治 具を用いて基板裹側から陰圧を加えることにより細胞を各 吸引孔に密着させ, 電気的に他の領域と隔絶させる。電気 信号は, 吸引孔開口部に存在する細胞のイオンチャネルか ら流れるイオン電流を基板上に形成した検出電極で計測す ることにより得ることが可能である。

64 個の検出電極より得られた細胞の電気信号は, 培地に 浸した参照電極を基準に, 外部に接続した MEA システム （信号増幅用アンプ，A/D 変換等）により増幅および低ノイ ズ化され, 個々のグラフにリアルタイムに検出される。

尚, 参照電極は $\mathrm{Ag} / \mathrm{AgCl}$ 電極を使用寸る。 $\mathrm{Ag} / \mathrm{AgCl}$ は電 子とイオン間の電荷の授受が可逆反応に従って滞りなく行 なわれることにより, 電極に電流が流れていない状態の静 止電極電位が安定しているためである。

\section{3. デバイス製作}

〈3・1〉製作プロセス 図 2 に本デバイスの製作プロ セスを示す。MEMS 技術を用いて製作する本デバイスの製 
作プロセスは大きく分けて下記 3 つに分類できる。

(i ) MCA 構造の製作

(ii) パリレン C による絶縁膜の形成

(iii) 白金黒電極製作のための白金めつき

$\mathrm{MCA}$ 構造の製作では，まず $\mathrm{Si}$ 基板（厚さ：250 $\mu \mathrm{m}$ ）表面 にエッチングマスクとして Cr (500 A) を真空蒸着した後, パターニングし, 高アスペクト比でシリコンを加工するこ とができる Deep-RIE (Reactive Ion Etching) 装置により微小 な細胞吸引孔を形成する (図 2(a))。同様の製作プロセスを, Si 基板裏面に直径 $100 \mu \mathrm{m}$ の吸引孔を形成するために行な い, 表面の細胞吸引孔と繋げる（図 2(b)）。その後, Si 基板 表面を絶縁するために熱酸化を行い（図 2(c)）, 電極の形成 となる。今回，電極パターンの面積に差があるため，ウェ ットエッチングでパターニングすることは困難であると判 断し, リフトオフレジスト（LOR 5A，化薬マイクロ・ケム 株式会社）によるリフトオフプロセスで形成する。 Ti/Pt を スパッタ装置により成膜し，上記リフトオフプロセスによ り検出電極を形成する（図 2(d)）。以上で, MCA 構造の製作 は完了となる。

次に, パリレン $\mathrm{C}$ による絶縁膜形成を行なう。パリレン $\mathrm{C}$ を化学的蒸着（CVD）法により成膜 $(1 \mu \mathrm{m})$ 後, $\mathrm{Al}(800$ A) をエッチングマスクとして RIE による $\mathrm{O}_{2}$ アッシングで パターニングを行う（図 2(e)）。エッチングマスクの材料は, パリレン C は急激な温度変化状況においてひび割れが生じ 易い材料である点を考慮し, 高熱で真空蒸着を行う $\mathrm{Cr}$ より も，低電流かつ低熱で真空蒸着を行うことが可能である $\mathrm{Al}$ をマスク材料として使用することにする。尚，パリレンの 密着性を向上させるために前処理（A-174 混合溶液浸漬）を 行なう。

最後に, 白金黒電極製作のための白金めっきを行なう（図 2(f)）。めつき作業は，白金めつき液(株式会社山本鍍金試験 器)中で 1 分毎に極性を変えながら行なう（対向電極 $: \mathrm{Pt}$ )。 長時間行なうとめつき時に生じる水素ガスの影響により絶 縁膜であるパリレン C が剥離したため, 電流值を上げてめ っき速度を速めることで白金めっきを行なう（10 mA， 5 min)。

〈3·2〉製作結果図 3 に本デバイスの製作結果を示 す。図 3(a)に本デバイスの全体写真を示す。デバイス全体サ イズは $40 \mathrm{~mm} \times 40 \mathrm{~mm}$ であり，デバイス中心部に細胞吸引 孔と検出電極を一体化した MCA 構造を製作した。計 64 極 あり, 電気的に絶縁された各検出電極はデバイス周辺部に 位置する電極パッド部に配線している。

図 3(b)に本デバイス中心部の拡大写真を示す。MCA 構造 がアレイ状に $8 \times 8$ の 64 極存在し, 細胞吸引孔間距離は 180 $\mu \mathrm{m}$ である。細胞吸引孔と一体化した部分の検出電極幅は, 設計通り $30 \mu \mathrm{m}$ に製作することができた。

図 3(c)に 1 チャンネルの拡大写真を示す。将来的に観察対 象とする細胞サイズ（約 $\Phi 10 \mu \mathrm{m} ）$ を考慮して設計した表面 細胞吸引孔径と絶縁膜開口部径は, 各々, $\Phi 5 \mu \mathrm{m}, \Phi 10 \mu \mathrm{m}$ 程度に製作することができた。しかしながら，ウェットエ

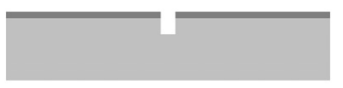

(a)

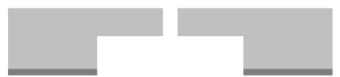

(b)

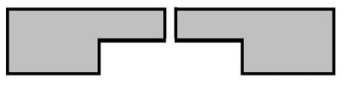

(c)

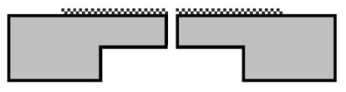

(d)

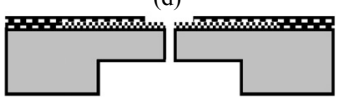

(e)

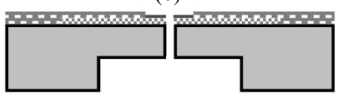

(f)
Si $\mathrm{Cr} \bigcirc \mathrm{SiO}_{2} \nRightarrow \mathrm{Ti} / \mathrm{Pt} \&$ Parylene Pt-black (a) $\mathrm{Cr}$ is patterned on the top side and $\mathrm{Si}$ is etched by Deep-RIE, (b) The same process is applied to the backside, (c) Thermal oxidation, (d) $\mathrm{Ti} / \mathrm{Pt}$ is patterned by lift-off process, (e) Insulating polymer is patterned, (f) Pt-black is electroplated.

Fig. 2. Fabrication process.

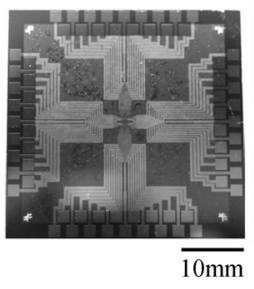

(a)

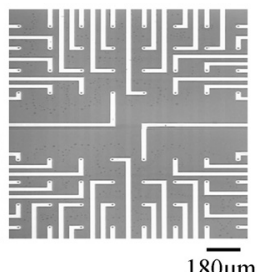

(b)

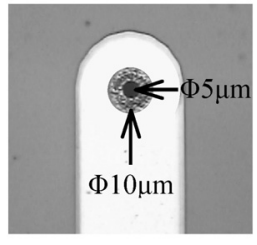

(c) (a) Whole view of $64 \mathrm{ch}$ isolated MCA, (b) 64 isolated Pt-black electrodes with respective suction holes are arranged, (c) Magnified view of suction hole $(\Phi 5 \mu \mathrm{m})$ and insulator hole $(\Phi 10 \mu \mathrm{m})$.

Fig. 3. Fabrication results.

ッチングやドライエッチング時によるサイドエッチングの 影響による誤差も生じており, 今後, その影響を考慮して, 設計や製作条件について検討する必要があると思われる。 また，検出電極部に白金黒電極を製作することができた。

絶縁膜材料として CRC-8300 使用時は, 細胞吸引孔の目詰 まりがあったが, 形状に均一に成膜できるパリレン C を導 入することにより細胞吸引孔の目詰まりも無くなった。表 面細胞吸引孔部分に滴下した純水をデバイス裏面から陰圧 を加えることにより吸引したところ, 純水の吸引を確認す ることができ, 細胞吸引孔の製作を確認することができた。

\section{4. デバイス評価実験}

〈4·1〉電極インピーダンス特性 観察対象の細胞外 電気信号レベルは数十 $\mu \mathrm{V}$ 数百 $\mu \mathrm{V}$ であり, $1 \mathrm{kHz}$ 程度の低 周波信号であると云われている。微小電極の場合は電極面 積が小さいため，電極インピーダンスによる制約が大きい。

$\mathrm{Cr} / \mathrm{Au}$ 電極を使用していた従来の個別計測用 MCA デバイ スにおける電極インピーダンスは，プレシジョン LCR ー ター (4284A，アジレント・テクノロジー株式会社) を用い て測定したところ, $1 \mathrm{kHz}$ で約 $600 \mathrm{k} \Omega$ であった。

MEA による細胞外計測電極のインピーダンスは, $1 \mathrm{kHz}$ で $100 \mathrm{k} \Omega$ 以下が適している(14)。本デバイスでは, 上記条件 を満たすために, 電極インピーダンスの低減について, 白 金黒（Pt-black）電極の導入に取り組んだ。同様に，LCRメ ーターを用い, $\mathrm{Ti} / \mathrm{Pt}$ 電極（標本数 : 1) と Ti/Pt-black 電極（標 本数：1）のインピーダンス測定を行った（図 4 参照）。図 4 


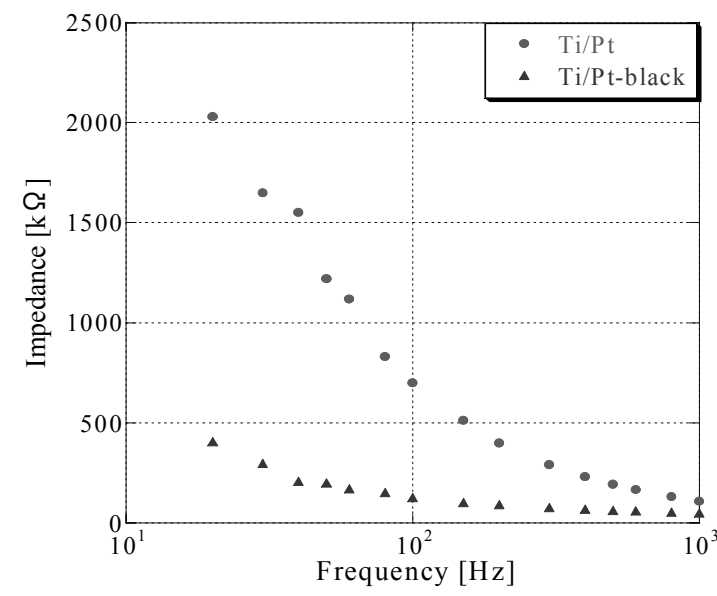

Fig. 4. Electrode impedance of Ti/Pt and Ti/Pt-black.

より，検出電極部に白金めつきを行うことで電極インピー ダンス值の更なる低減を確認することができ, 製作した Ti/Pt-black 電極においては, $1 \mathrm{kHz}$ で約 $80 \mathrm{k} \Omega$ を得ることが できた。

以上のことより，本デバイスによる細胞外電気信号計測 の実現に十分期待することができる。

$\langle 4 \cdot 2\rangle$ 自発活動電位の多点同時計測 吸引固定の特 徵を生かした細胞間ネットワークの観測に向けた第 1 段階 として, 観察対象に 2〜3 日齢のウィスターラット新生児急 性スライス（大脳皮質スライス）を使用し，吸引固定の有 無における多点同時信号計測の検証を行なう。今回，スラ イスを使用する利点として，下記 2 点を挙げることができ る。

（i ） 単一細胞の細胞吸引孔通り抜けの防止

(ii ) 周囲の細胞からの栄養補給による長期計測可能

スライサー装置を使用してスライス作製を行い，厚さは 数百 $\mu \mathrm{m}$ 程度である。作製直後のスライスは大きな損傷を受 けて興奮状態であるため, 蔗糖を加えた人工脳春髄液中に 入れて混合ガス $\left(95 \% \mathrm{O}_{2}, 5 \% \mathrm{CO}_{2}\right)$ によりバブリングを行 う。作製したスライスに酸素を十分行き渡らせることによ り，正常に近い状態で保存することが可能である。

図 5 に，本デバイス上に設置した大脳皮質急性スライス の写真を示す。計測系は, 神保らが開発した MEA システム を使用し，信号増幅用アンプ (NF 回路ブロック), 自作の ソフトウェア等から成っている。スライスを載せた本デバ イスを設置した吸引用治具を MEA システムに設置し， 64 本の電極プローブを降下させ，デバイスの電極パッドと接 触させる。参照電極 $(\mathrm{Ag} / \mathrm{AgCl})$ は, 観測対象も存在する, 本デバイス上に設置した PDMS (Polydimethylsiloxane) チャ ンバ内の培地に浸す。尚, 今回使用した培地の組成は,

$\mathrm{NaCl}: 148 \mathrm{mM}, \mathrm{KCl}: 2.8 \mathrm{mM}, \mathrm{CaCl}_{2}: 2 \mathrm{mM}, \mathrm{MgCl}_{2}: 1 \mathrm{mM}$, HEPES : $10 \mathrm{mM}$, Glucose : 10mM, pH : $7.2[3.6 \mathrm{ml}: 1 \mathrm{M} \mathrm{NaOH}]$ である。

各検出電極からの信号は MEA システムにより増幅され, 64 チャンネルの信号変化がリアルタイムに計測できる。信

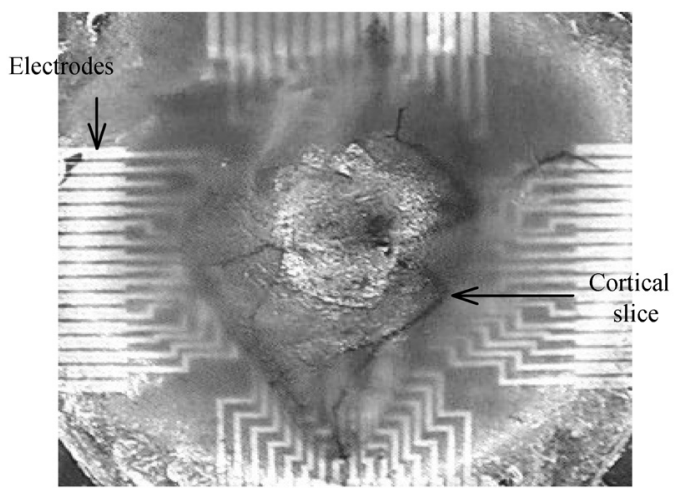

Fig. 5. Photograph of cortical slice on $64 \mathrm{ch}$ isolated MCA.

号増幅用アンプの増幅度は 2,000 倍, バンドパスフィルタ值 は $10 \mathrm{~Hz} \sim 5 \mathrm{kHz}$ に設定した。ノイズレベルに関しては，培 地をデバイス上に滴下して導通試験を行ったところ, $10 \mu \mathrm{V}_{\mathrm{pp}} \sim 30 \mu \mathrm{V}_{\mathrm{pp}}$ といった細胞外計測に特に影響は無いもの と考えられる低レベルのノイズが得られた。

吸引固定時におけるラット大脳皮質急性スライスの多点 同時信号計測結果を図 6 に示す。図6(a)に, 特に顕著な自発 活動電位計測が確認できたチャンネル部のグラフを示す。 図 6(a)より, 本デバイスを用いて, スライスにおける自発活 動電位の多点同時計測を確認することができた。

また, 図 6(a)の中の 1 つの自発活動電位波形を拡大したグ ラフを図 6(b)に示す。図6(b)からわかるように，スパイク電 位のレベルは約 $150 \mu \mathrm{V}$, 反応時間は約 $2 \mathrm{msec}$ である。一般 的に計測される細胞外信号のスパイク電位波形（レベル： 約数十 $\mu \mathrm{V} \sim$ 数百 $\mu \mathrm{V}$, 反応時間 : 約数 msec） とほぼ同様で あるため，本デバイスによるラット大脳皮質スライスの細 胞外自発活動電位計測を確認することができた。

本実験では，吸引固定無しの状態で信号計測を確認する ことが出来ず，その後吸引固定することで確認することが できた。よって, 本デバイスの吸引固定機能を用いること により, 従来の MEA では困難な観測状況を改善できる，す なわち $\mathrm{S} / \mathrm{N}$ 比に優れた観測が可能である利点を示すことが できたといえる。

〈4·3〉 デバイス上における細胞培養＼cjkstart本デバイス は, 基板表面に検出電極を形成している。個々の電極を電 気的に絶縁し, 観察対象以外の細胞からのノイズを防ぐた め, 検出電極を絶縁材でコーティングする必要がある。従 来の個別計測用 MCA デバイスでは, 絶縁膜材料として CRC-8300 を使用していたが，培養開始約 1 週間で基板から 剥離してしまうため, 長期培養に向けて高い生体適合性か つ基板への密着性を有するパリレン $\mathrm{C} へ$ 変更に取り組む。 パリレン C 上での細胞培養状況を確認するために, ラッ 卜胎児の海馬神経細胞 $(\Phi 10 \mu \mathrm{m}$ 前後 $)$ をポリリジンコーテ イングしたデバイス上に撒布し, $37{ }^{\circ} \mathrm{C}$, 水蒸気飽和, $5 \% \mathrm{CO}_{2}$ の条件下で培養実験を行った。図 7 にデバイス上での培養 1 週間後における写真を示す。図 7 からわかるように, 本デ バイス上で神経細胞同士が神経軸索によるネットワークを 組んでいる様子を確認することができた。また，培地に浸 


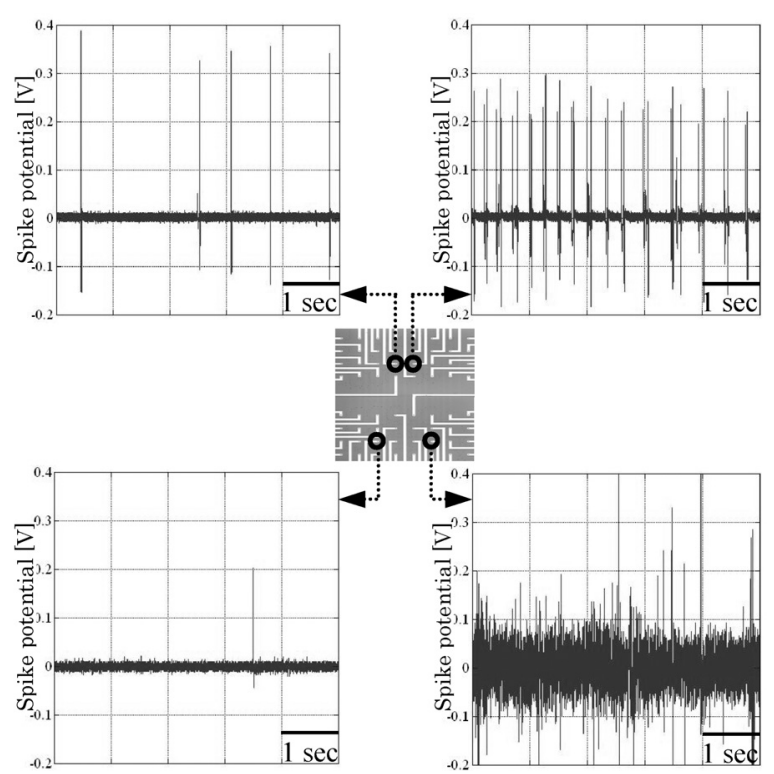

(a) Simultaneous multipoint measurements

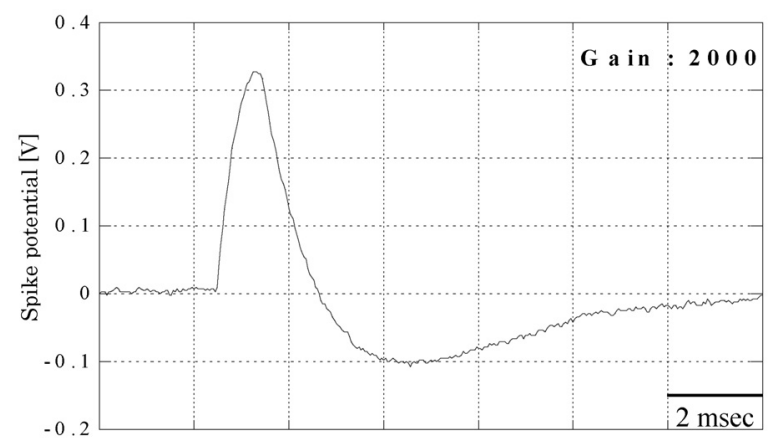

(b) Close-up of a spontaneous spike potential.

Fig. 6. Spontaneous activity of cortical slice in suction.

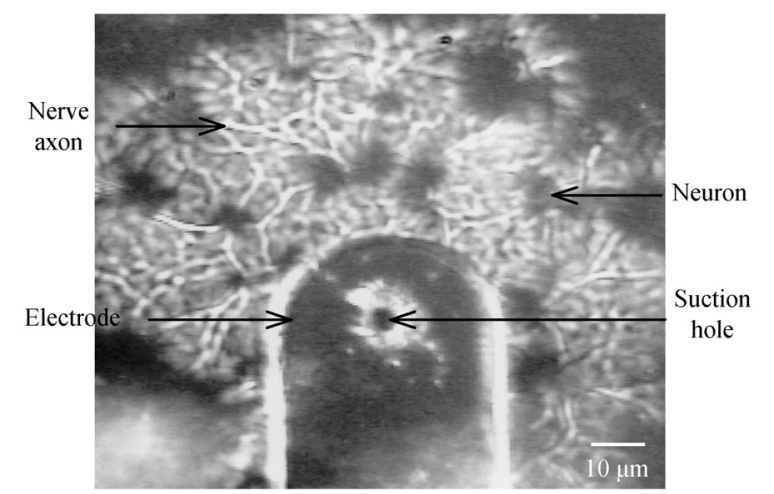

Fig. 7. Photograph of cultured hippocampal neurons on $64 \mathrm{ch}$ isolated MCA.

ることによるパリレン膜の剥離が生じていないことも確認 することができた。このことから，本デバイスに絶縁膜と して使用しているパリレン $\mathrm{C}$ 上で細胞の培養が可能である ことを確認することができた。

以上のことより，本デバイス上の細胞間ネットワークの 観測の可能性を十分期待することができる。

$\langle 4 \cdot 4\rangle$ 考 察 吸引固定機能を有した本デバイス
による，細胞間ネットワークの効果的な観測の実現に向け た第 1 段階として, 下記 3 点を確認することができた。

( i ) 電極インピーダンスの低減化

(ii) スライス自発活動電位の多点同時計測

(iii) デバイス上での細胞培養

とりわけ，吸引固定時にのみスライス自発活動電位の多 点同時計測を確認できた点に, 本デバイスによる吸引固定 の有用性を示すことができたといえる。

以上の結果を踏まえ, 電気的に独立した 1 つの検出電極 に 1 個の細胞吸引孔が対応している本デバイスは, 細胞を 1 つずつ所定の位置に固定してその成長を制御することで, 従来の MEA に比べて $\mathrm{S} / \mathrm{N}$ 比と細胞選択性に優れた効果的な 細胞間ネットワークの観測が可能であると考えられる。

その実現に向けて，デバイスの更なる改善および各吸引 孔への新たな細胞誘導機能の付加に取り組む予定である。

\section{5. 結言}

本稿では, 従来の個別計測用 MCA デバイスの更なる改良 に取り組み, 吸引固定による細胞閒ネットワークの効果的 な観測を目指した細胞間ネットワーク解析用 MCA デバイ スの設計・製作および評価実験について述べた。細胞吸引 孔と検出電極を一体化した MCA 構造は, 細胞間ネットワー クにおける多点同時計測を実現するために, 電気的に独立 したチャンネルがアレイ状に 64 極ある。検出電極材料は白 金黒を導入し，電極インピーダンスの低減を実現できた。

評価実験は, 第 1 段階としてラット大脳皮質スライスを 観察対象として信号計測を行い, 吸引固定時における自発 活動電位の多点同時計測を確認することができた。また, 細胞間ネットワーク解析に向けた次段階として，本デバイ ス上でラット海馬神経細胞の培養実験を行い, 細胞間ネッ トワークの形成を確認することができた。

以上の結果を踏まえ, MCA 構造の吸引固定の有用性を確 かめることができ, 従来の MEA に比べて, S/N 比と細胞選 択性に優れた効果的な細胞間ネットワーク観測ツールとし ての可能性を示すことができたといえる。

\section{謝 辞}

本研究は, 平成 17 年度文部科学省科学研究費補助金特定 領域研究「生体分子群のデジタル精密計測に基づいた細胞 機能解析 : ライフサーベイヤ」によりなされたことを記す。

(平成 19 年 3 月 26 日受付, 平成 19 年 7 月 3 日再受付)

\section{文献}

(1) B. Matthews and J. W. Judy : "Design and Fabrication of a Micromachined Planar Patch-Clamp Substrate with Integrated Microfluidics for SingleCell Measurements", Journal of Microelectromechanical Systems, Vol.15, No.1, pp.214-222 (2006-2)

(2) F. J. Sigworth and K. G. Klemic : "Microchip Technology in Ion-Channel Research", IEEE Transactions on Nanobioscience, Vol.4, No.1, pp.121-127 (2005-3)

( 3 ) R. Pantoja, J. M. Nagarah, D. M, Starace, N. A. Melosh, R. Blunck, F. Bezanilla, and J. R. Heath : "Silicon Chip-based Patch-clamp Electordes 
Integrated with PDMS Microfluidics", Biosensors and Bioelectronics, Vol.20, pp.509-517 (2004-2)

( 4 ) C. Wood, C. Williams, and G. J. Waldron : "Patch Clamping by Numbers", Drug Discovery Today, Vol.9, No.10, pp.434-441 (2004-5)

( 5 ) N. Fertig, R. H. Blick, and J. C. Behrends : "Whole Cell Patch Clamp Recording Performed on a Planar Glass Chip", Biophysical Journal, Vol.82, pp.3056-3062 (2002-6)

(6) I. Suzuki, Y. Sugio, H. Moriguchi, A. Hattori, K. Yasuda, and Y. Jimbo : "Pattern modification of a neuronal network for individual-cell-based electrophysiological measurement using photothermal etching of an agarose architecture with a multielectrode array", IEE Proc.Nanobiotechnol., Vol.151, No.3, pp.116-121 (2004-6)

( 7 ) Y. Jimbo, N. Kasai, K. Torimitsu, T. Tateno, and H. P. C. Robinson : “A System for MEA-Based Multisite Stimulation”, IEEE Transactions on Biomedical Engineering, Vol.50, No.2, pp.241-248 (2003-2)

( 8 ) U. Egert, S. Okujeni, W. Nisch, K. H. Boven, R. Rudorf, N. Gottschlich, and A. Stett : "Optimized Oxygen Availability and Signal-to-Noise Ratio in Brain Slice Recordings with Perforated Microelectorde Arrays", Proc. $5^{\text {th }}$ Int. Meeting on Substrate-Integrated Microelectrodes, pp.174-177, Reutlingen, Germany (2006-7)

( 9 ) S. Yamaguchi, H. Isejima, T. Matsuo, R. Okura, K. Yagita, M. Kobayashi, and H. Okamura : "Synchronization of Cellular Clocks in the Suprachiasmatic Nucleus", Science, Vol.302, pp.1408-1412 (2003-11)

(10) M. Tanabe, J. Makinodan, K. Suzuki, Y. Hosokawa, S. Konishi, N. Ozaki, and H. Oka : "Development of Micro Channel Array with Detecting Electrodes for Electrophysiological Biomedical Sensor", Proc. IEEE Conf. on Micro Electro Mechanical Systems, pp.407-410, Kyoto, Japan (2003-1)

(11) K. Suzuki, M. Tanabe, T. Ezaki, S. Konishi, H. Oka, and N. Ozaki : "The Electrophysiological Biosensor for Batch-Measurement of Cell Signals", IEEJ Trans. SM, Vol.125-E, No.5, pp.216-221 (2005-5)

(12) S. Konishi, K. Suzuki, W. Tonomura, R. Kitazawa, T. Ueyama, and H. Okamura : "Electrophysiological Biosensor with Micro Channel Array for Multipoint Measurement of Signals from Distributed Cells", Proc. of the $3^{\text {rd }}$ Annual International IEEE EMBS Conf. on Microtechnologies in Medicine and Biology, pp.371-374, Hawaii, U.S.A. (2005-5)

(13) W. Tonomura, R. Kitazawa, T. Ueyama, H. Okamura, and S. Konishi "Electrophysiological Biosensor with Micro Channel Array for Sensing of Signals from Single Cells", Proc. IEEE Conf. on SENSORS, pp.140-143, Daegu, Korea (2006-10)

(14) J. Pine : "Studying Mammalian Neurons in vitro with Multielectorde Arrays", Proc. of the $25^{\text {th }}$ Annual International Conf. of the IEEE EMBS, pp.3686-3689, Cancun, Mexico (2003-9)

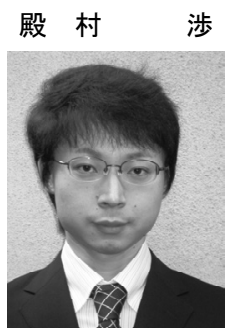

（非会員） 2005 年 3 月立命館大学理工学部機械 工学科卒業。2007 年 3 月同大学大学院理工学研 究科情報システム学専攻博士課程前期課程修 了。同年 4 月同大学大学院理工学研究科総合理 工学専攻博士課程後期課程進学, 現在に至る。 主として, MEMS 技術を用いた細胞および細胞 ネットワーク解析用ツールの研究に従事。

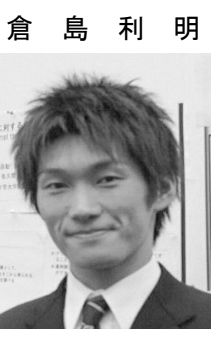

(非会員) 1982 年 5 月 22 日生。 2005 年 3 月名 古屋大学工学部機械航空工学科卒業。現在東京 大学大学院新領域創成科学研究科人間環境学 専攻修士課程 2 年在学中。In Vitro において感 覚系の再構成を行い, 神経回路や組織レベルで どのような処理が行われているか, その解明を 目指している。

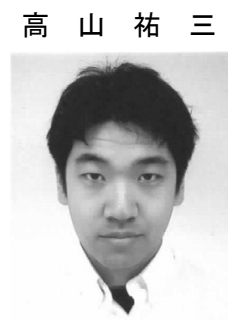

(非会員) 2005 年東京大学工学部システム創成 学科卒業。現在東京大学大学院新領域創成科学 研究科人間環境学専攻博士課程在学中。微細加 工技術, 光学測定を始めとした工学技術を用 い, 脳神経系の構築・機能制御の機構を明らか にする研究に従事。

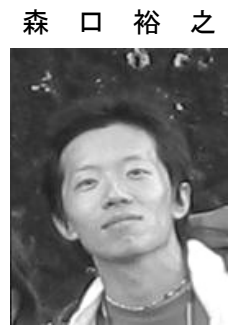

（非会員） 1977 年 8 月 8 日生。 2006 年 3 月東 京大学大学院総合文化研究科修了, 学術博士。 同年 4 月日本学術振興会特別研究員。多細胞組 織の構築と機能の仕組みについて独自の実験 と切り口で理解を進めて行きたいという考え で技術開発と生理学実験を行っている。日本生 物物理学会会員。

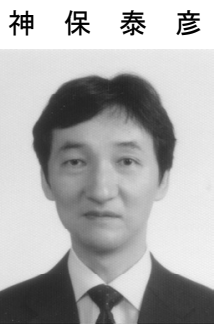

(正員) 1988 年東京大学大学院（電子工学) 修了, 工学博士。同年, NTT 基礎研究所研究員。 1992-1993 年, フランス CNRS 客員研究員。2003 年, 東京大学大学院工学系研究科精密機械工学 専攻助教授, 2006 年より同新領域創成科学研究 科人間環境学専攻教授。主として, 神経工学の 研究に従事。電子情報通信学会, 神経科学学会, 日本生体医工学会, IEEE 等の会員。

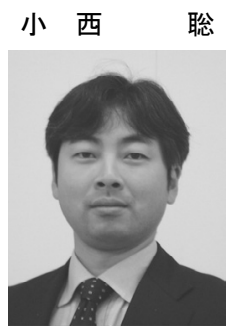

(正員) 1991 年東京大学工学部電子工学科卒 業。1993 年同大学大学院博士課程前期課程修 了, 1996 年同後期課程修了, 博士 (工学)。同 年 4 月より立命館大学理工学部専任講師。1 1999 年 4 月より同助教授。2006 年 4 月より同教授, 現在に至る。2002-2003 年, カリフォルニア工 科大学客員研究員。MEMS 全般に関する研究を 行う中で, 特にマイクロアクチュエータとその 応用に関する研究を重視。機械学会, 応用物理学会, 日本ロボット 学会, IEEE 会員。 